\title{
Safe sites for tree regeneration in wooded pastures: A case of associational resistance?
}

\author{
Smit, Christian ${ }^{1 *}$; Béguin, Daniel ${ }^{2}$; Buttler, Alexandre ${ }^{2,3,4} \&$ Müller-Schärer, Heinz ${ }^{1}$ \\ ${ }^{1}$ Department of Biology, Unit of Ecology \& Evolution, University of Fribourg, Chemin du Musée 10, CH-1700 Fribourg, \\ 3 \\ Switzerland; ${ }^{2}$ Swiss Federal Research Institute WSL-Antenne romande, CP 96, CH-1015 Lausanne, Switzerland; \\ ${ }^{4}$ Laboratoire de Chrono-écologie, UMR 6565 CNRS, UFR des Sciences et Techniques, Université de Franche- \\ Comté, F-25030 Besançon, France; ${ }^{*}$ Corresponding author; Fax+41 263009740; E-mail christian.smit@unifr.ch
}

\begin{abstract}
Question: Are tree saplings in wooded pastures spatially associated with specific nurse structures or plants that facilitate tree sapling survival?

Location: Wooded pastures in the Jura Mountains, Switzerland.

Methods: In two sites, $73 \mathrm{~km}$ apart, we sampled 294 plots of $4 \mathrm{~m}^{2}$, systematically distributed on $1 \mathrm{ha}$. We recorded number and height of all established Picea abies saplings ( $>1$ a of age and up to $40 \mathrm{~cm}$ in height), and visually estimated cover of rocks, shrubs, tree stumps, overhanging tree branches and unpalatable plant species.

Results: Despite differences in site characteristics, we found overall positive effects of cover of unpalatable plants, rocky outcrops and tree stumps on the density of Picea saplings. Plots with tree stumps and higher cover of rocky outcrops and unpalatable plants were more likely to contain Picea saplings. Conclusions: Unpalatable plants, rocky outcrops and tree stumps seem to form safe sites for Picea saplings in this grazed system, improving their establishment and survival. Our findings support the idea that associational resistance drives the dynamics of wooded pastures, but experimental evidence for this hypothesis is still required.
\end{abstract}

Keywords: Facilitation; Grazing; Nurse plant; Picea abies; Tree establishment; Tree sapling.

Nomenclature: Tutin et al. (1964-1980).

\section{Introduction}

Spatial associations of tree saplings with other vascular plant species, often shrubs, are found in several ecosystems, including savannas and grasslands (Rousset \& Lepart 1999, 2000; Weltzin \& McPherson 1999), woodlands (Chambers 2001), mountain shrub steppes and forests (Callaway et al. 1996), chaparral (Dunne \& Parker 1999) and laurel forests. These associations often suggest nurse effects of the neighbouring plants, through direct or indirect contributions to the performance of the saplings by (1) providing shelter from ex- treme temperatures and high irradiance; (2) increasing water availability (water uplift, higher water infiltration rate and reduced evaporation); (3) improving nutrient availability; (4) offering physical support; (5) reducing soil compaction and erosion or (6) protecting from herbivores (e.g. Flores \& Jurado 2003). Detecting spatial associations helps to understand dynamics of ecosystems.

Close association with unpalatable plants, defended by physical or chemical mechanisms, in cattle-grazed ecosystems can reduce herbivory on tree saplings, leading to spatial associations of tree saplings (Rousset \& Lepart 1999; Kuiters \& Slim 2003; Bakker et al. 2004). This process, also known as associational resistance or defence guilds (Atsatt \& Odowd 1976) is proposed as a key process in the dynamics of grazed temperate woodlands leading to cyclic shifts in vegetation mosaics (shifting mosaic theory, Olff et al. 1999): unpalatable plants in open grassland facilitate other unattractive high forbs and shrubs, which facilitate trees, which outcompete in turn their original facilitators. Since undergrowth and hence tree regeneration underneath these trees is prevented, open grassland may reappear after the tree dies. Thus, the landscape remains a mosaic of grassland and forest patches. The cattle-driven cyclic shifts are seen as highly important for the maintenance of spatial and temporal variation in vegetation structure, leading to high biodiversity in extensively grazed ecosystems in temperate zones (Olff \& Ritchie 1998).

Wooded pastures or pastured woodlands are traditional semi-natural ecosystems, combining extensive pasturing and logging with natural regeneration of grassland and woodland. Wooded pastures may find their origin in the Neolithic with the first farming activities of man (Pott \& Hüppe 1991), but it has also been hypothesized that domesticated animals have taken over the role of their now-extinct ancestors (e.g. aurox, tarpan) in maintaining similar vegetation patterns (Vera 2000). Wooded pastures have declined drastically in Europe during the last few decades, mostly due to concentration of agricul- 
tural management, leading to local intensification and abandonment elsewhere (Gillet \& Gallandat 1996; Pywell et al. 2002). Considerable areas of wooded pastures are still to be found in the Swiss Jura Mountains, at altitudes between 900 and 1400 m (Gillet \& Gallandat 1996). These species-rich landscapes with high conservation values are now highly threatened. The dynamics of these systems are yet little investigated and a better understanding is crucial for sustainable management and conservation purposes.

The objective of our study was to determine whether established tree saplings were spatially associated with potential nurse structures, such as shrubs, tree stumps, rock outcrops, overhanging tree branches and unpalatable plants, as predicted by the associational resistance hypothesis. A positive association is the prerequisite for associational resistance, the suggested key process in the dynamics of these wooded pastures, although it could be generated by other processes as well.

\section{Methods}

\section{Study sites}

This study was conducted in two wooded pastures, ca. $73 \mathrm{~km}$ apart, lying in the central part of the Swiss Jura Mountains (Table 1). The climate is continental, with some Atlantic depressions. Mean annual temperature is $3-5^{\circ} \mathrm{C}$. Annual precipitation is $1400-2000 \mathrm{~mm}$ but soils are relatively dry because of the high permeability of the underlying calcareous layers (Gallandat et al. 1995). In combination with low winter temperatures, this leads to a relatively short growing season of ca. four months. Every year, the ground is covered with snow during ca. 120 days between November and April.

The landscape is geomorphologically and geologically heterogeneous. The vegetation mosaic consists of closed forest patches mainly on rock outcrops and steep

Table 1. Characteristics of the study sites and pasturing conditions for the year 2002.

\begin{tabular}{|c|c|c|}
\hline Site & 1. La Sagne & 2. Marchairuz \\
\hline Coordinates & $6^{\circ} 47^{\prime} \mathrm{N}, 47^{\circ} 3^{\prime} \mathrm{E}$ & $6^{\circ} 12^{\prime} \mathrm{N}, 46^{\circ} 32^{\prime} \mathrm{E}$ \\
\hline Size (ha) & 400 & $102\left(15^{* 1}\right)$ \\
\hline Altitude (m a.s.1.) ${ }^{* 2}$ & 1150 & 1340 \\
\hline Slope $\left({ }^{\circ}\right)^{* 2}$ & 16 & 15.7 \\
\hline Aspect & $\mathrm{S}$ & $\mathrm{N}$ \\
\hline Grazing system & Free ranging & Four rotations \\
\hline No. of grazing days & 112 & $108\left(40^{* 1}\right)$ \\
\hline No. of animals & 369 cows, 15 horses & 50 cows, 3 horses \\
\hline Grazing period & mid-May - end Sept. & end May - end Sept. \\
\hline Grazing intensity*3 & $50 \mathrm{LU}$ days/ha & 82 LU days/ha \\
\hline \multicolumn{3}{|c|}{$\begin{array}{l}{ }^{*} \text { Size selected park; }{ }^{* 2} \text { Mean values; }{ }^{* 3} \text { Estimated value; } 1 \text { LU (livestock } \\
\text { unit) }=600 \mathrm{~kg} \text { body weight. Grazing intensity calculated as: (nr. LU * nr. } \\
\text { grazing days) / total grazed area. }\end{array}$} \\
\hline
\end{tabular}

slopes, and pastures on flat surfaces or gentle slopes where the soils are more favourable for agriculture. Picea abies is the naturally dominant tree species, occurring as isolated individuals or in small groups in open grasslands. Acer pseudoplatanus, Abies alba and Fagus sylvatica occur infrequently in the surrounding ungrazed forests and are rare in the wooded pastures.

The mainly dry, calcareous grasslands are mostly of the Mesobrometum type, harbouring some of the most species-rich plant communities of Central Europe (Gallandat et al. 1995; Schläpfer et al. 1998; Vittoz 1998; Pykala 2003).

Two grazing systems are commonly applied: 'freeranging' where animals spend the whole grazing season roaming freely through unpartitioned pastures, and 'rotation-grazing' where pastures are divided in parks and animals pass from one park to another according to a variable period of rotation (Gillet \& Gallandat 1996). Cattle, sometimes mixed with horses, are generally brought up to the pastures in May and transported back at the end of September.

In each site we selected a representative surface with the constraint of having a tree cover ranging from 20 to $60 \%$, dominated by Picea abies and with occurrence of young trees. Site 1 is situated in the Communal de la Sagne and is grazed by free ranging cattle. Site 2 is situated in Marchairuz (Pré-aux-Veaux), and belongs to the larger Parc Jurassien Vaudois. It is divided into roughly even sized parks, which are grazed in turns (rotation system); our selected park measured ca. 15 ha. The herd grazes eight to ten days per park before passing to the next. Aside from occasional roe deer Capreolus capreolus and alpine hare, Lepus timidus, no other large vertebrate herbivores have been observed at our study sites.

\section{Data collection}

All field work was carried out between June and October 2002. At each study site we established 150 plots of $4 \mathrm{~m}^{2}$ on ten transect lines, 15 plots per line, with a total area of ca. 1 ha. Lines were $10 \mathrm{~m}$ apart and plots along lines were $5 \mathrm{~m}$ apart. In each plot the number and height of Picea abies saplings ( $>1$ year old, up to $40 \mathrm{~cm}$ in height) were recorded and we visually estimated percentage cover of: (1) rocks (uncovered rocky outcrops); (2) shrubs (woody shrub species $>40 \mathrm{~cm}$ tall); (3) overhanging tree branches $(<150 \mathrm{~cm})$; (4) tree stumps and (5) unpalatable plant species (from an $a$ priori list) using the scale of Braun-Blanquet (1964). Cover scores were converted to percentage median values for statistical analyses. Picea seedlings emerging in the current year ( $<1$ year old) were not recorded since we would have measured effects of the 'nurse' structures on seed germination and emergence, rather than on 
establishment and survival. Saplings $>40 \mathrm{~cm}$ tall were not included since some of these were actually relatively old (ca. > 50 years, unpubl.), but remained small due to constant browsing by cattle, and could have outcompeted their original facilitators.

The a-priori list of unpalatable species was derived from literature and personal observations (species left untouched by cattle after a grazing season), and mainly contained relatively large obviously unpalatable plant species, i.e. tall species with clear mechanical defences like spines and thorns or with well established toxic chemical compounds. These were Cirsium acaule, $C$. eriophorum, Carduus defloratus, Carlina acaulis (mechanically defended), Gentiana lutea, Veratrum album, Atropa bella-donna, Urtica dioica, and Ranunculus aconitifolium (all chemically defended). We encountered the following shrub species: Rosa canina, R. pendulina, Rubus idaeus, $R$. saxatilis, $R$. fruticosus, Ribes alpinus, Crataegus monogyna (all physically defended), and Juniperus communis (both physically and chemically defended). These species were recorded as unpalatable when present as small individuals in the herb layer (single stemmed, $<40 \mathrm{~cm}$ ), since we considered them not yet fully able to offer physical protection against cattle.

\section{Data analyses}

We compared the two sites for differences in sapling density, number of plots with tree saplings and percentage cover of rocks, shrubs, tree stumps, overhanging tree branches and unpalatable plants per plot. Data were analysed with Mann-Whitney $U$-tests.

To estimate the impact of the cover of the five potential facilitative variables on sapling density, we fitted generalised linear models (GLM), with a negative binomial distribution and a log-ratio link function. Count data are generally analysed using Poisson distributions or, when variances exceed the means and when many cells are empty, negative binomial distributions (Krebs 1999). We ran these analyses for each site separately using all valid plots: 150 for site 1,144 for site 2 . When significant effects of an explanatory variable were found, Tukey's honestly significant difference (HSD) tests were used to test for significance of differences between the different pairs of group means.

In order to get an overview of the overall effects of the five potential facilitative elements on tree sapling density, we pooled data from the two sites together and run a GLM, again with a negative binomial distribution and a log-ratio link function. We added 'site' as an explanatory variable. Tukey's HSD tests were used for comparing pairs of group means of the significant variables.

We used Genstat 7 for the GLMs and SPSS release 11.5 for all other statistical analyses.

\section{Results}

\section{Sapling recordings}

We recorded a total of 433 established Picea abies saplings in the two sites. Most saplings measured $0-4$ $\mathrm{cm}$ in height (70\%), and were estimated to be $1-2$ years old (pers. obs.). All other tree saplings (30\%) were estimated to be over 2 years old. Saplings $>40 \mathrm{~cm}$ tall were few, but consistently present. This, together with observations of isolated small trees in the sites, suggests ongoing recruitment to larger size classes; some seedlings become saplings, and some saplings grow to maturity.

\section{Differences between sites}

Site 1 harboured more tree saplings than site 2 (Table 2). The range of sapling density per plot varied between $0-15$ and $0-11$ for site 1 and 2, respectively. Furthermore, sites differed in number of full plots (plots containing Picea saplings), sapling density per full plot and mean cover of rocks and shrubs (Mann-Whitney $U$ tests, $p<0.05$ ). Shrub cover was more common in site 1 than in site 2 , while rock cover was generally higher in site 2 . Tree stumps were relatively rare in both sites: only 11 plots contained stumps.

\section{Effects of potential facilitative elements per site}

The GLMs on sapling density per plot revealed significant positive effects of cover of rocks and non-palatability in site 1 and of cover of tree stumps in site 2 (Table $3)$. The significant models $\left(p<0.001, \chi^{2}\right)$ explained $14.1 \%$ (site 1 ) and $12.4 \%$ (site 2) of the deviance. Reducing the models by leaving out variables stepwise did not improve the models (not shown). There were no significant interactions between the variables and they were therefore excluded from the models.

When comparing the means of between levels for each significant factor using Tukey's HSD test, we found a higher sapling density at the higher cover levels of rock, unpalatable, and tree stump cover. At site 1, plots with a rock cover of $\geq 10 \%$, and an unpalatable cover of $\geq 25 \%$ contained more Picea saplings. At site 2 , plots with tree stump cover had a higher mean sapling density than plots without.

\section{Effects of potential facilitative elements, pooled over sites}

Analysis of the pooled data (over both sites) revealed significant effects of site and rock-, unpalatableand tree stump cover on sapling density (Table 3 ). The 
Table 2. Data on Picea abies saplings and facilitative structures at the two sites.

\begin{tabular}{|c|c|c|c|c|c|c|c|c|c|}
\hline \multirow[b]{2}{*}{ Site } & \multirow[b]{2}{*}{ Cover type } & \multirow[b]{2}{*}{ Mean \pm SD $(\%)$} & \multicolumn{7}{|c|}{ Frequencies per cover type level } \\
\hline & & & $0 \%$ & $0-1 \%$ & $1-5 \%$ & $5-25 \%$ & $25-50 \%$ & $50-75 \%$ & $75-100 \%$ \\
\hline 1. La Sagne & Rock & $3.88 \pm 8.31$ & 79 & 25 & 21 & 16 & 9 & 0 & 0 \\
\hline Plots $\left(4 \mathrm{~m}^{2}\right)=150$ & Shrub & $4.52 \pm 15.21$ & 119 & 11 & 4 & 5 & 4 & 5 & 2 \\
\hline No. of saplings $=343$ & Stump & $0.73 \pm 5.43$ & 142 & 3 & 2 & 1 & 1 & 1 & 0 \\
\hline No. of full plots $=94$ & Tree branches & $8.15 \pm 18.0$ & 96 & 7 & 11 & 16 & 11 & 6 & 3 \\
\hline Sapling density / full plot $=3.65 \pm 3.05$ & Unpalatable & $7.86 \pm 9.65$ & 25 & 28 & 40 & 43 & 14 & 0 & 0 \\
\hline 2. Marchairuz & Rock & $5.82 \pm 11.44$ & 31 & 45 & 37 & 21 & 6 & 4 & 0 \\
\hline Plots $\left(4 m^{2}\right)=144$ & Shrub & $0.91 \pm 3.24$ & 129 & 1 & 6 & 8 & 0 & 0 & 0 \\
\hline Nr. Saplings $=90$ & Stump & $0.42 \pm 3.12$ & 141 & 2 & 1 & 0 & 0 & 0 & 0 \\
\hline $\mathrm{Nr}$ full plots $=45$ & Tree branches & $9.16 \pm 21.36$ & 103 & 1 & 9 & 12 & 5 & 9 & 5 \\
\hline Sapling density / full plot $=2.00 \pm 1.59$ & Unpalatable & $7.36 \pm 8.99$ & 9 & 14 & 75 & 37 & 8 & 1 & 0 \\
\hline
\end{tabular}

significant model $\left(p<0.001, \chi^{2}\right)$ explained $24.84 \%$ of the deviance. Sapling density was significantly higher in site 1. Fig. 1 shows the effects per level of cover on saplings density: plots with a higher cover of rocks, unpalatable plants and tree stumps contained a higher sapling density.
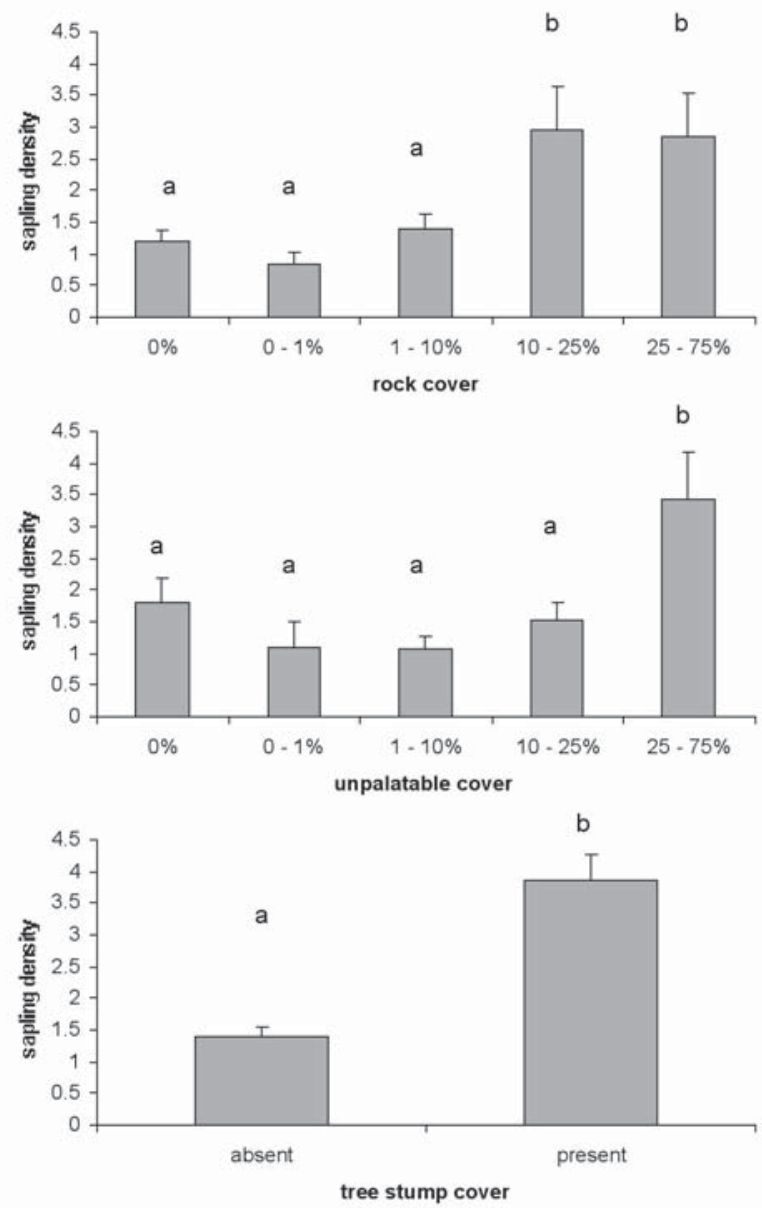

Fig. 1. Mean sapling density $(+\mathrm{SE})$ per plot for each level of the significant factors tree stump,unpalatable and rock cover. Data are pooled over both sites. Different letters indicate statistically significant differences at $p<0.05$ (Tukey HSD test).

\section{Discussion}

\section{Spatial associations and selective grazing}

In this study we found that plots with higher cover of rocky outcrops, unpalatable plants and tree stumps were more likely to contain Picea saplings than plots with no or low cover of these. This was true despite differences between the sites in grazing system (free ranging versus rotation), grazing intensity, altitude and climatic factors (Table 1). Although we are well aware of the constraints of the correlative nature of this study, these results suggest that spatial associations of Picea recruitment with unpalatable plants, rocky outcrops and tree stumps may be a general feature in wooded pasture ecosystems. This pattern could reflect positive effects on tree saplings by unpalatable plants, rocky outcrops and tree stumps as an indirect effect of selective grazing behaviour. Foraging behaviour studies have shown that ungulates generally graze selectively and concentrate on short, leafy swards containing relatively high nutrient concentrations (Wallis deVries et al. 1999). Patches of little nutritious value, avoided by grazers, often occur on rocky shallow soils, tree stumps or where unpalatable plants are prevalent. Tree saplings establishing in or near such patches could, therefore, be protected against both trampling and grazing by large herbivores, as has also been proposed by other authors in studies on grazed ecosystems (Vera 2000; Rousset \& Lepart 2000). Most of these studies, however, focused on spatial associations of palatable tree species (Quercus spp.) with shrubs in grazed environments, and experimental evidence concerning mechanisms for this association is still scarce (but see Bakker et al. 2004). Here, we show an example of spatial associations of a tree species (Picea abies) in its sapling phase with unpalatable, high-statured herbaceous or woody plants, rocky outcrops and tree stumps in a grazed system. It seems that even relatively unpalatable tree species like Picea may benefit from associational resistance: cattle may browse 
Table 3. Results of generalized linear models, with a negative binomial distribution and a log-ratio link function, with tree sapling density per $4-\mathrm{m}^{2}$ plot as response variable, for each site and with data pooled over sites. Independent predictor variables include percentage cover of rocks, unpalatables, shrubs, tree stumps, overhanging tree branches and site (2 vs 1$)$. $*=p<0.05 ; * *=p<0.01 ; * * *=p<0.001$.

\begin{tabular}{|c|c|c|c|c|c|c|c|c|c|}
\hline \multirow[b]{2}{*}{ Parameter } & \multicolumn{3}{|c|}{ Site $1(n=150)$} & \multicolumn{3}{|c|}{ Site $2(n=144)$} & \multicolumn{3}{|c|}{ Sites $1+2(n=294)$} \\
\hline & Estimate $+\mathrm{SE}$ & $d f$ & $t$ & Estimate $+\mathrm{SE}$ & $d f$ & $t$ & Estimate $+\mathrm{SE}$ & $d f$ & $t$ \\
\hline Constant & $-0.515 \pm 0.055$ & 1 & $-9.32 * * *$ & $-1.167 \pm 0.131$ & 1 & $-8.94 * * *$ & $-0.546 \pm 0.054$ & 1 & $-10.11 * * *$ \\
\hline Site & & & & & & & $-0.575 \pm 0.084$ & 1 & $-6.81 * * *$ \\
\hline Rocks & $0.009 \pm 0.002$ & 1 & $4.87 * * *$ & $0.008 \pm 0.005$ & 1 & 1.55 & $0.010 \pm 0.002$ & 1 & $5.80 * * *$ \\
\hline Unpalatables & $0.008 \pm 0.002$ & 1 & $3.18 * * *$ & $0.008 \pm 0.008$ & 1 & 1.10 & $0.009 \pm 0.002$ & 1 & $3.74 * * *$ \\
\hline Shrubs & $-0.002 \pm 0.003$ & 1 & -0.79 & $0.018 \pm 0.018$ & 1 & 1.01 & $-0.003 \pm 0.002$ & 1 & -1.07 \\
\hline Stumps & $0.004 \pm 0.004$ & 1 & 1.16 & $0.027 \pm 0.005$ & 1 & $4.93 * * *$ & $0.271 \pm 0.097$ & 1 & $2.79 * *$ \\
\hline Branches & $0.0005 \pm 0.002$ & 1 & 0.27 & $-0.003 \pm 0.005$ & 1 & -0.58 & $0.001 \pm 0.002$ & 1 & 0.17 \\
\hline
\end{tabular}

unprotected saplings by chance because of their tasty surroundings and avoid an unpalatable patch with a luckier sapling.

We also expected to find a higher sapling density in plots with a higher cover of potential facilitative structures, assuming that these would offer (1) a larger suitable area for tree seeds to arrive, germinate and establish and (2) a better protection against cattle. A higher sapling density in plots with a high cover of nurse structures could furthermore indicate that the proportional cover of nurse structures per plot has an influence on the selection behaviour of cattle. Our data show evidence for these expectations, as plots with tree stumps and a higher cover of rocky outcrops and unpalatable plants had higher sapling densities.

According to two succession models (Bokdam et al. 2001; Olff et al. 1999) woody invasion in grazed grasslands will start after reduced grazing pressure, induced by declining palatability of the lawn species (i.e. mostly grasses and sedges). We did not consider the effects of these smaller species in this study. Nevertheless, preliminary results of another experiment in the same study sites showed that some of these smaller unpalatable species are significantly more often present near Picea abies saplings than in plots without these (unpubl.). This would indicate that associational resistance may also be active at a smaller scale, involving subordinate herbs.

\section{Other potential processes involved}

Besides selective herbivory there are a few alternative explanations for the observed spatial distribution of Picea saplings. Some studies on spatial distribution of seeds and saplings report both nursing- and seed trapping effects (de Viana et al. 2001; Weltzin \& McPherson 1999). Both an increased seed input near tall (nurse) structures via the catching of seeds (seed trapping) and improved germination conditions under the canopy of nurse structures led to a relatively higher density of seeds and saplings. Others (Jurena \& Archer 2003) report that above- and below-ground gaps in the grass layer were the main contributors to tree sapling establishment. In our studied system, rocky outcrops, unpalatable plants and tree stumps may act as seed traps for the mainly wind dispersed Picea abies seeds, or form particularly suitable microsites for seed germination.

Although tree stumps only occurred in 11 out of the 294 plots, they appeared to have particularly strong positive effects on sapling density. All these plots contained tree saplings, with a density of 2-6 saplings per plot. Similar positive effects of tree stumps, roots and logs on Picea regeneration were found in boreal swamp forests in Sweden, where the elevated micro-relief with rotten wood offered saplings favourable moisture, aeration, light conditions, nutrients, mycorrhizal fungi and absence of resource competition with other plants (Hörnberg et al. 1997). However, these boreal forests were not grazed, and the protective role of tree stumps against herbivory may be an additional factor.

Rock outcrops could, besides offering physical protection, improve the conditions for Picea seeds and seedlings by affecting local temperature. In early spring, rocky outcrops generally warm up faster than their environment, causing local snow melt, which may favour germination of seeds. In addition, established seedlings may profit from a prolonged growing season near rocky outcrops in this relatively harsh environment.

The observed associations of established Picea saplings with unpalatable plants, rocky outcrops and tree stumps could, hence, be caused by several processes. However, since we excluded newly emerged seedlings ( $<1$ year old) from recording and found tree saplings of variable height classes in close proximity to the three types of structures, it is unlikely that we observed only the effects of germination improvement. Clearly, more research is needed to further investigate and disentangle the mechanisms contributing to the observed spatial associations of the Picea abies saplings. Nevertheless, we conclude that unpalatable plant species, rocky outcrops and tree stumps can have positive effects for Picea 
abies recruitment in wooded pastures of the Swiss Jura Mountains. The observed spatial associations are consistent with the shifting mosaic cycle from open grasslands to woodlands. Experiments to further test the associational resistance hypothesis are presently under way.

Acknowledgements. We thank Kerry Woods, Han Olff and two other anonymous referees for helpful comments on an earlier draft of this manuscript. This project was partly funded by the National Centre of Competence in Research (NCCR) Plant Survival and the NRP-48 on landscapes and habitats of the Alps, both research programs of the Swiss National Science Foundation.

\section{References}

Atsatt, P.R. \& Odowd, D.J. 1976. Plant defense guilds. Science 193: 24-29.

Bakker, E.S., Olff, H., Vandenberghe, C., de Maeyer, K., Smit, R., Gleichman, J.M. \& Vera,F.W.M. 2004 . Ecological anachronisms in the recruitment of temperate lightdemanding tree species in wooded pastures. J.Appl.Ecol. 41: 571-582.

Bokdam, J., Cornelius, R. \& Krüsi, O. 2001. A conceptual model for nutrient-mediated successional grazing mosaics. Natur- und Kulturlandschaft 4: 122-131.

Braun-Blanquet, J. 1964. Pflanzensoziologie. Grundzüge der Vegetationskunde. Springer, Berlin, DE.

Callaway, R.M., DeLucia, E.H., Moore, D., Nowak, R. \& Schlesinger, W.H. 1996. Competition and facilitation: Contrasting effects of Artemisia tridentata on desert vs montane pines. Ecology 77: 2130-2141.

Chambers, J.C. 2001. Pinus monophylla establishment in an expanding Pinus-Juniperus woodland: Environmental conditions, facilitation and interacting factors. J. Veg. Sci. 12: $27-40$.

de Viana, M.L., Suhring, S. \& Manly, B.F.J. 2001. Application of randomization methods to study the association of Trichocereus pasacana (Cactaceae) with potential nurse plants. Plant Ecol. 156: 193-197.

Flores, J. \& Jurado, E. 2003. Are nurse-protégé interactions more common among plants from arid environments? J. Veg. Sci. 14: 911-916.

Gallandat, J. D., Gillet, F., Havlicek, E. \& Perrenoud, A. 1995. Typologie et systémique phyto-écologique des pâturages boisées du Jura Suisse. Rapport de Mandat, Institut de botanique, Université de Neuchâtel, Neuchâtel, CH.

Gillet, F. \& Gallandat, J.D. 1996. Wooded pastures of the Jura Mountains. In: Etienne, M. (ed.) Western European silvopastoral systems, pp. 37-53. Institut national de la recherche agronomique, Paris, FR.

Hörnberg, G., Ohlson, M. \& Zackrisson, O. 1997. Influence of bryophytes and microrelief conditions on Picea abies seed regeneration patterns in boreal old-growth swamp forests. Can.J.For. Res. 27: 1015-1023.

Jurena, P.N. \& Archer, S. 2003. Woody plant establishment and spatial heterogeneity in grasslands. Ecology 84: 907919.

Krebs, C.J. 1999.Ecological methodology.2nd ed.Cummings, Menlo Park, CA, US.

Kuiters, A.T. \& Slim, P.A. 2003. Tree colonisation of abandoned arable land after 27 years of horse-grazing: the role of bramble as a facilitator of oak wood regeneration. Forest Ecol. Manage. 181: 239-251.

Olff, H. \& Ritchie, M.E. 1998. Effects of herbivores on grassland plant diversity. Trends Ecol. Evol. 13: 261-265.

Olff, H., Vera, F.W.M., Bokdam, J., Bakker, E.S., Gleichman, J.M., de Maeyer, K.D. \& Smit, R. 1999. Shifting mosaics in grazed woodlands driven by the alternation of plant facilitation and competition. Plant Biol. 1: 127-137.

Palmer, S.C.F., Hester, A.J., Elston, D.A., Gordon, I.J. \& Hartley, S.E. 2003. The perils of having tasty neighbors: Grazing impacts of large herbivores at vegetation boundaries. Ecology 84: 2877-2890.

Pott, R. \& Hüppe, J. 1991. Die Hudelandschaften Nordwestdeutschlands. Westfälisches Museum für Naturkunde, Landschaftsverband Westfalen-Lippe, Veröffentlichung der Arbeitsgemeinschaft für biologisch-ökologische Landeserforschung, ABÖL, Nr. 89, Münster, DE.

Pykala, J. 2003. Effects of restoration with cattle grazing on plant species composition and richness of semi-natural grasslands. Biodiv. Conserv. 12: 2211-2226.

Pywell, R.F., Bullock, J.M., Hopkins, A., Walker, K.J., Sparks, T.H., Burke, M.J.W. \& Peel, S. 2002. Restoration of species-rich grassland on arable land: assessing the limiting processes using a multi-site experiment. J.Appl.Ecol. 39: 294-309.

Rousset, O. \& Lepart, J. 1999. Shrub facilitation of Quercus humilis regeneration in succession on calcareous grasslands. J. Veg. Sci. 10: 493-502.

Rousset, O. \& Lepart, J. 2000. Positive and negative interactions at different life stages of a colonizing species (Quercus humilis). J. Ecol. 88: 401-412.

Schläpfer, M., Zoller, H. \& Körner, C. 1998. Influences of mowing and grazing on plant species composition in calcareous grassland. Bot. Helv. 108: 57-67.

Vera, F.W.M. 2000. Grazing ecology and forest history. CAB International, Oxon, UK.

Vittoz, P. 1998. Flore et végétation du Parc jurassien vaudois: typologie, écologie et dynamique des milieux. Faculté des Sciences de l'Université de Lausanne, $\mathrm{CH}$.

Wallis de Vries, M.F., Laca, E.A. \& Demment, M.W. 1999. The importance of scale of patchiness for selectivity in grazing herbivores. Oecologia 121: 355-363.

Weltzin, J.F. \& McPherson, G.R. 1999. Facilitation of conspecific sapling recruitment and shifts in temperate savanna ecotones. Ecol. Monogr. 69: 513-534. 